\title{
Two new neolignans from Manglietia insignis
}

\author{
Shan-Zhai SHANG, ${ }^{\text {a,b }}$ Ju-Ming YAN,,${ }^{\text {a, }}$ Hai-Bo ZHANG, ${ }^{\text {a }}$ Yi-Ming SHI, ${ }^{\text {a,b }}$ Zhong-Hua GAO, ${ }^{\text {a,b }}$ Xue Du, ${ }^{\text {a }}$ \\ Yan LI, ${ }^{\mathrm{a}}$ Wei-Lie XIAO, ${ }^{\mathrm{a}, *}$ and Han-Dong SuN ${ }^{\mathrm{a}, *}$ \\ ${ }^{a}$ State Key Laboratory of Phytochemistry and Plant Resources in West China, Kunming Institute of Botany, Chinese \\ Academy of Sciences, Kunming 650201, Yunnan, China \\ ${ }^{\mathrm{b}}$ University of Chinese Academy of Sciences, Beijing 100049, China
}

Received 26 July 2012; Accepted 17 October 2012

(C) The Author(s) 2012. This article is published with open access at Springerlink.com

\begin{abstract}
Two new neolignans, manneoinsigins A (1) and B (2), together with four known lignans, were isolated from the leaves and stems of Manglietia insignis. The new compounds were established on the basis of extensive spectroscopic analyses. All compounds except $\mathbf{2}$ were tested for their cytotoxic activity. Compound $\mathbf{3}$ showed weak cytotoxic activity against the HL-60 human tumor cell line with the $\mathrm{IC}_{50}$ value of $23.5 \mu \mathrm{M}$.
\end{abstract}

Keywords: Magnoliaceae, Manglietia insignis, neolignan, cytotoxic activity

\section{Introduction}

Plants of the family Magnoliaceae are mainly distributed in southeastern Asia, which contain more than 250 species and are a rich source of lignans possessing various pharmacological functions. ${ }^{1-9}$ Structural and biological diversity of lignans in magnoliaceae family prompted us to investigate Magnolia insignis Rehd. et Wils, a plant widely distributed in the west of China and being partly used as a substitute of $M$. officinalis in Yunnan and Sichuan provinces of China. ${ }^{4,10}$ As a result, two new neolignans, manneoinsigins A (1) and B (2), together with other four known lignans, scaphopetalone (3), ${ }^{11}$ mesosecoisolariciresinol (4), ${ }^{12}$ lariciresinol $(5)^{13}$ and evafolin B (6) ${ }^{14}$ were isolated. Herein, the isolation, structural elucidation, and their cytotoxic activity are described.

\section{Results and Discussion}

Manneoinsigin A (1) was obtained as yellow gum. The negative ESIMS of 1 showed characteristic peaks for $[\mathrm{M}-\mathrm{H}]$ and $[\mathrm{M}-\mathrm{H}+2]^{-}$with the ratio being $3: 1$, which suggested the presence of a chlorine atom. The molecular formula of $\mathbf{1}$ was determined as $\mathrm{C}_{18} \mathrm{H}_{19} \mathrm{O}_{4} \mathrm{Cl}$ by its HRESIMS with a pseudomolecular ion peak at $m / z 333.0897[\mathrm{M}-\mathrm{H}]^{-}$, corresponding to nine unsaturation degrees. The ${ }^{1} \mathrm{H}$ NMR spectrum displayed signals due to two sets of ABX-type aromatic systems $\left(\delta_{\mathrm{H}} 7.28,6.91\right.$ and $7.24 ; \delta_{\mathrm{H}} 7.08,6.84$ and $7.02)$, one terminal double bond $\left(\delta_{\mathrm{H}} 5.00,5.05\right.$ and 5.97), two methylenes $\left(\delta_{\mathrm{H}} 3.33\right.$ and 3.61), and two methines $\left(\delta_{\mathrm{H}} 4.67\right.$ and

\footnotetext{
*To whom correspondence should be addressed. E-mail: xwl@mail.kib.ac.cn (W.L. Xiao); hdsun@mail.kib.ac.cn (H.D. Sun)
}

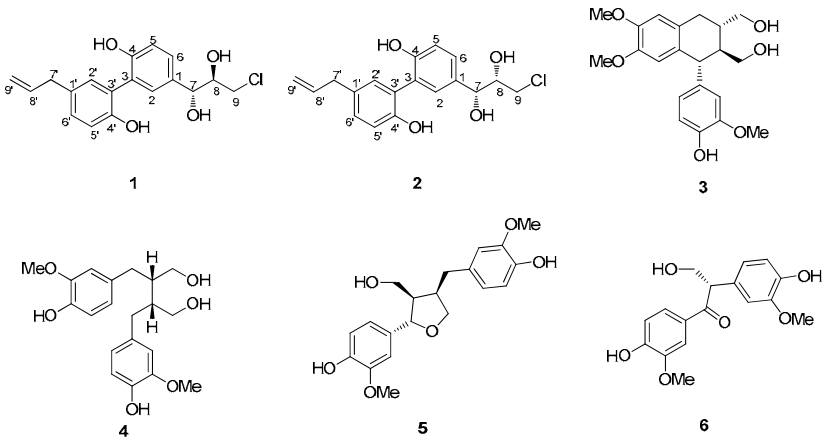

Figure 1. The structures of compounds 1-6

3.85) (Table 1). The ${ }^{13} \mathrm{C}$ NMR (DEPT) spectrum exhibited eighteen carbon signals, consisting of fourteen $s p^{2}$ ones (two of which were signals of allyl group at $\delta_{\mathrm{C}} 115.6$ and 139.4), two methylenes, and two oxygenated methines (Table 1). Comparison of 1D NMR spectra of 1 with those of magnolol showed that they possessed the same skeleton. ${ }^{15}$ The differences could be rationalized to be that the allyl group in magnolol was replaced by a 1,2-dihydroxy-3-chlorine-propyl group in 1. This was further supported by the HMBC correlations of H-7 $\left(\delta_{\mathrm{H}} 4.67,1 \mathrm{H}, \mathrm{d}, J=5.9 \mathrm{~Hz}\right)$ with $\mathrm{C}-1\left(\delta_{\mathrm{C}}\right.$ $134.2), \mathrm{C}-2\left(\delta_{\mathrm{C}} 131.3\right), \mathrm{C}-6\left(\delta_{\mathrm{C}} 128.2\right), \mathrm{C}-8\left(\delta_{\mathrm{C}} 76.9\right)$ and $\mathrm{C}-9$ $\left(\delta_{\mathrm{C}} 47.3\right)$, together with the ${ }^{1} \mathrm{H}-{ }^{1} \mathrm{H}$ COSY correlations of $\mathrm{H}-7 / \mathrm{H}-8 / \mathrm{H}_{2}-9$ (Fig. 2). Furthermore, the HMBC correlations of H-7 with C-1, C-2 and C-6 indicated that the 1,2-dihydroxy-3chlorine-propyl group was located at $\mathrm{C}-1$ (Fig. 2). The chlorine atom was deduced to be located at C-9 by the characteristic chemical shift of C-9 at $\delta_{\mathrm{C}} 47.3$.

\section{照 Springer}


Table 1. ${ }^{1} \mathrm{H}$ and ${ }^{13} \mathrm{C}$ NMR spectroscopic assignments of compounds 1 and $2^{\mathrm{a}}$

\begin{tabular}{|c|c|c|c|c|}
\hline \multirow[b]{2}{*}{ position } & \multicolumn{2}{|l|}{1} & \multicolumn{2}{|l|}{2} \\
\hline & $\delta_{\mathrm{H}}^{\mathrm{b}}$ & $\delta_{\mathrm{C}}{ }^{\mathrm{c}}$ & $\delta_{\mathrm{H}}{ }^{\mathrm{b}}$ & $\delta_{\mathrm{C}}^{\mathrm{c}}$ \\
\hline 1 & & $134.2 \mathrm{~s}$ & & $134.0 \mathrm{~s}$ \\
\hline 2 & $7.28(\mathrm{~d}, 2.0)$ & $131.3 \mathrm{~d}$ & $7.30(\mathrm{~s})$ & $131.6 \mathrm{~d}$ \\
\hline 3 & & $127.7 \mathrm{~s}$ & & $128.4 \mathrm{~s}$ \\
\hline 4 & & $155.2 \mathrm{~s}$ & & $156.5 \mathrm{~s}$ \\
\hline 5 & $6.91(\mathrm{~d}, 8.3)$ & $117.4 \mathrm{~d}$ & $6.88(\mathrm{~d}, 8.2)$ & $117.9 \mathrm{~d}$ \\
\hline 6 & $7.24(\mathrm{dd}, 8.3,2.0)$ & $128.2 \mathrm{~d}$ & $7.22(\mathrm{~d}, 8.2)$ & $128.7 \mathrm{~d}$ \\
\hline 7 & $4.67(\mathrm{~d}, 5.9)$ & $75.4 \mathrm{~d}$ & $4.56(\mathrm{~d}, 6.8)$ & $75.8 \mathrm{~d}$ \\
\hline 8 & $3.85(\mathrm{~m})$ & $76.9 \mathrm{~d}$ & $3.88(\mathrm{~m})$ & $76.5 \mathrm{~d}$ \\
\hline 9 & $3.61(\mathrm{dd}, 11.4,4.0) ; 3.33$ (overlap) & $47.3 \mathrm{t}$ & $3.77(\mathrm{dd}, 11.2,2.7) ; 3.67(\mathrm{dd}, 11.2,6.7)$ & $48.1 \mathrm{t}$ \\
\hline $1^{\prime}$ & & $133.0 \mathrm{~s}$ & & $132.6 \mathrm{~s}$ \\
\hline $2^{\prime}$ & $7.08(\mathrm{~d}, 2.0)$ & $132.7 \mathrm{~d}$ & $7.13(\mathrm{~s})$ & $132.6 \mathrm{~d}$ \\
\hline $3^{\prime}$ & & $127.6 \mathrm{~s}$ & & $128.2 \mathrm{~s}$ \\
\hline $4^{\prime}$ & & $153.6 \mathrm{~s}$ & & $154.7 \mathrm{~s}$ \\
\hline $5^{\prime}$ & $6.84(\mathrm{~d}, 8.2)$ & $117.4 \mathrm{~d}$ & $6.82(\mathrm{~d}, 8.1)$ & $118.0 \mathrm{~d}$ \\
\hline $6^{\prime}$ & $7.02(\mathrm{dd}, 8.2,2.0)$ & $129.8 \mathrm{~d}$ & $7.00(\mathrm{~d}, 8.1)$ & $129.8 \mathrm{~d}$ \\
\hline $7^{\prime}$ & 3.36 (overlap) & $40.4 \mathrm{t}$ & 3.34 (overlap) & $40.7 \mathrm{~d}$ \\
\hline $8^{\prime}$ & $5.97(\mathrm{~m})$ & $139.4 \mathrm{~d}$ & $5.98(\mathrm{~m})$ & $139.8 \mathrm{~d}$ \\
\hline $9^{\prime}$ & $5.05(\mathrm{dd}, 17.0,1.6) ; 5.00(\mathrm{dd}, 10.2,1.6)$ & $115.6 \mathrm{t}$ & 5.05 (br. d, 17.0); 5.00 (br. d, 9.9) & $115.6 \mathrm{t}$ \\
\hline
\end{tabular}

${ }^{\mathrm{a}}$ Recorded in methanol- $d_{4}$; ${ }^{\mathrm{b}}$ Recorded at $600 \mathrm{MHz} ;{ }^{\mathrm{c}}$ Recorded at $125 \mathrm{MHz}$.

Manneoinsigin B (2) was obtained as yellow gum. The presence of a chlorine atom was deduced by the characteristic peaks for $[\mathrm{M}-\mathrm{H}]^{-}$and $[\mathrm{M}-\mathrm{H}+2]^{-}$with the ratio being $3: 1$ in its negative ESIMS. The molecular formula of $\mathbf{2}$ was deduced as $\mathrm{C}_{18} \mathrm{H}_{19} \mathrm{O}_{4} \mathrm{Cl}$ from its HREIMS $\left(\mathrm{m} / z 334.0964[\mathrm{M}]^{+}\right)$. Detailed analysis of the 1D NMR data of 1 and $\mathbf{2}$ suggested that both of them had the same plane structure (Table 1). It was found that the differences of the ${ }^{1} \mathrm{H}$ NMR chemical shifts of H-7 and H-9 from $\delta_{\mathrm{H}} 4.67,3.61$, and 3.33 in 1 changing to $\delta_{\mathrm{H}} 4.56,3.77$, and 3.67 in 2 and the ${ }^{13} \mathrm{C}$ NMR chemical shifts of C-7, C-8 and C-9 from $\delta_{\mathrm{C}} 75.4,76.9$, and 47.3 in 1 changing to $\delta_{\mathrm{C}} 75.8,76.5$, and 48.1 . The reason for the minor distinct NMR data of $\mathbf{1}$ and $\mathbf{2}$ could be rationalized to the dissimilar configurations of the stereogenic carbons of the side chains.

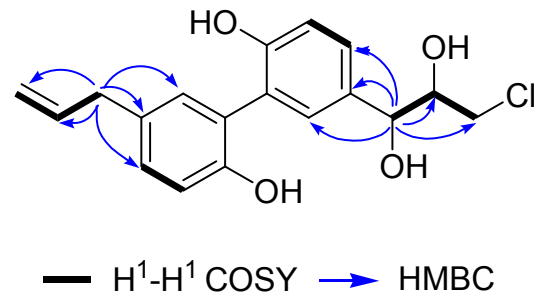

Figure 2. Selected 2D NMR correlations of 1

The $\mathrm{OH}$ configurations of two stereogenic centers in $\mathbf{1}$ and $\mathbf{2}$ were determined by comparison with the ${ }^{13} \mathrm{C}$ NMR data of the structural similar compounds, erythro- and threo-honokitriol ${ }^{16}$ and erythro- and threo-1-C-syringylglycerol. ${ }^{17}$ The difference of ${ }^{13} \mathrm{C}$ NMR chemical shifts of $\mathrm{C}-7\left(\delta_{\mathrm{C}} 76.0\right)$ and $\mathrm{C}-8\left(\delta_{\mathrm{C}} 76.2\right)$ in erythro-honokitriol is $\Delta \delta_{\mathrm{C}-8-\mathrm{C}-7} 0.2$, which is smaller than that in threo-honokitriol $\left(\Delta \delta_{\mathrm{C}-8(77.8)-\mathrm{C}-7(74.6)} 3.2\right) .{ }^{16}$ In addition, the difference of ${ }^{13} \mathrm{C}$ NMR chemical shifts of $\mathrm{C}-7\left(\delta_{\mathrm{C}} 74.1\right)$ and $\mathrm{C}-8\left(\delta_{\mathrm{C}} 75.3\right)$ in erythro-1-C-syringylglycerol is $\Delta \delta_{\mathrm{C}-8-\mathrm{C}-7}$ 1.2 , which is also smaller than that in its threo-isomer $\left(\Delta \delta_{\mathrm{C}-}\right.$ 8(75.8)-C-7(72.9) 2.9). ${ }^{17}$ Therefore, the relative configurations of 1 and 2 could also be determined base on the rules as mentioned in the above cases. ${ }^{16,17}$ In compound 2, the difference of the carbon signals of C-7 $\left(\delta_{\mathrm{C}} 75.8\right)$ and C-8 $\left(\delta_{\mathrm{C}} 76.5\right)$ is $\Delta \delta_{\mathrm{C}-8-\mathrm{C}-7}$
0.7, which is smaller than that in $\mathbf{1}\left(\Delta \delta_{\mathrm{C}-8(76.9)-\mathrm{C}-7(75.4)} 1.5\right)$. Thus, the structures of $\mathbf{1}$ and $\mathbf{2}$ were determined as threo- and erythro- configurations, respectively. As for the absolute configuration of $\mathrm{C}-7$ and $\mathrm{C}-8$, there should be four possibilities, i.e. $(7 R, 8 R),(7 R, 8 S),(7 S, 8 R)$, and $(7 S, 8 S)$. In the literature, four stereoisomers of 1 -phenylglycidol with $(1 R, 2 R),(1 R, 2 S)$, $(1 S, 2 R),(1 S, 2 S)$ configurations were synthesized by an asymmetric method, and the optical data were $[\alpha]_{D}^{18}-45.5(c$ $\left.3.3),[\alpha]_{\mathrm{D}}^{25}-38.5(c 2.2),[\alpha]_{\mathrm{D}}^{20}+37.2(c) 3.4\right),[\alpha]_{\mathrm{D}}^{21}+45.0(c$ $2.4)$, respectively. ${ }^{18}$ By comparison of their optical data with those of threo isomer $\left(\mathbf{1},[\alpha]_{\mathrm{D}}^{23.5}-11.0\right)$ and erythro isomer $(\mathbf{2}$, $\left.[\alpha]_{\mathrm{D}}^{20}-14.6\right)$, it was confirmed that the configuration of $\mathrm{C}-7$ and $\mathrm{C}-8$ in 1 and $\mathbf{2}$ were $(7 R, 8 R)$ and $(7 R, 8 S)$, respectively.

Some chemical constituents from the Magnoliaceae family were reported to have obvious cytotoxic activities. ${ }^{1,9}$ Therefore, all compounds except compound 2 were assayed for their cytotoxicity against the HL-60, SMMC-7721, A-549, MCF-7, and SW-480 human tumor cell lines by the MTT method with cis-platin as positive control. ${ }^{19}$ Compound $\mathbf{3}$ showed weak cytotoxic activity against the HL-60 human tumor cell lines with the $\mathrm{IC}_{50}$ values of $23.5 \mu \mathrm{M}$. The other compounds did not show cytotoxic activity $\left(\mathrm{IC}_{50}>40 \mu \mathrm{M}\right)$.

\section{Experimental Section}

General Experimental Procedures. Optical rotations were measured with a JASCO DIP-370 digital polarimeter. UV spectra were obtained using a Shimadzu UV-2401A spectrophotometer. A BioRad FtS-135 spectrophotometer was used for scanning IR spectroscopy with $\mathrm{KBr}$ pellets. $1 \mathrm{D}$ and 2D NMR spectra were recorded on Bruker AM-400, DRX-500 and Bruker Avance III-600MHz spectrometers. Unless otherwise specified, chemical shifts $(\delta)$ were expressed in ppm with reference to the solvent signals. High resolution electrospray ionization (HRESIMS) were performed on a VG Autospec3000 spectrometer under $70 \mathrm{eV}$. Column chromatography was performed using silica gel (200-300 mesh, Qingdao Marine Chemical, Inc., Qingdao, China). Semi-preparative HPLC was performed on an Agilent 1100 liquid chromatograph with a Zorbax SB- $\mathrm{C}_{18}, 9.4 \mathrm{~mm} \times 25 \mathrm{~cm}$, column. Preparative HPLC was performed on a Shimadzu LC-8A preparative liquid chromatograph with a Shimadzu PRC-ODS (K) column. 
Fractions were monitored by TLC and spots were visualized by heating the silica gel plates sprayed with $10 \% \mathrm{H}_{2} \mathrm{SO}_{4}$ in EtOH.

Plant Materal. The leaves and stems of M. insignis (Wall.) Bl. was collected in Kunming Botanic Garden, Yunnan Province, China, in August 2007. The specimen was identified by Prof. Xun GONG and a voucher specimen (No. KIB 200708-11) has been deposited at the State Key Laboratory of Phytochemistry and Plant Resources in West China, Kunming Institute of Botany, Chinese Academy of Sciences.

Extraction and Isolation. The air-dried plant material of $M$. insignis $(6.5 \mathrm{~kg})$ was ground and exhaustively percolated three times with $70 \%$ aqueous $\mathrm{Me}_{2} \mathrm{CO}$ at room temperature. The solvent was evaporated in vacuo, and the combined crude extract was dissolved in $\mathrm{H}_{2} \mathrm{O}$ and partitioned with EtOAc. The EtOAc portion (156 g) was subsequently chromatographed on a silica gel column eluting with $\mathrm{CHCl}_{3}-\mathrm{Me}_{2} \mathrm{CO}(1: 0,9: 1,8: 2$, $2: 1,1: 1$, and $0: 1)$ and was combined into six groups (A-F) according to TCL analysis. Fraction B (21g) was chromatographed on MPLC eluting with $\mathrm{MeOH} / \mathrm{H}_{2} \mathrm{O}$ (30:70-100:0 gradient system), to give fraction $\mathrm{B} 1-\mathrm{B} 5$. And then fraction B3 was further applied to silica gel $\mathrm{CC}$, and eluted with petroleum ether-acetone $(20: 1,12: 1,8: 1$ and $3: 1)$ to give five fractions B3-1-B3-5. Compounds $1\left(7.0 \mathrm{mg}, \mathrm{t}_{\mathrm{R}}=29 \mathrm{~min}\right)$ and $2\left(2.1 \mathrm{mg}, \mathrm{t}_{\mathrm{R}}=32 \mathrm{~min}\right)$ were obtained from fraction B3-2 by semi-preparative HPLC ( $42 \%$ aq. acetonitrile, $3 \mathrm{~mL} / \mathrm{min})$. Fraction B3-3 was chromatographed on Sephadex LH-20 $(\mathrm{MeOH})$ and then successively chromatographed on silica gel $\mathrm{CC}\left(\mathrm{CHCl}_{3}\right.$-ethyl acetate, 25:1, 16:1, 12:1 and 6:1) to give compound $6(12 \mathrm{mg})$. Fraction B4 was further purified on silica gel $\mathrm{CC}\left(\mathrm{CHCl}_{3}\right.$-ethyl acetate, 24:1-8:1) and then chromatographed on Sephadex LH-20 (MeOH) to give six fractions B4-1-B4-6. Fraction B4-2 were further subjected to semi-preparative HPLC ( $53 \%$ aq. $\mathrm{MeOH}, 3 \mathrm{~mL} / \mathrm{min})$ to afford $3\left(9.0 \mathrm{mg}, \mathrm{t}_{\mathrm{R}}=18 \mathrm{~min}\right)$ and $4\left(14.6 \mathrm{mg}, \mathrm{t}_{\mathrm{R}}=24 \mathrm{~min}\right)$. Compound $5\left(5.6 \mathrm{mg}, \mathrm{t}_{\mathrm{R}}=18 \mathrm{~min}\right)$ were purified by semipreparative $\mathrm{HPLC}(55 \%$ aq. $\mathrm{MeOH}, 3 \mathrm{~mL} / \mathrm{min})$ from fraction B4-3.

Manneoinsigin A (1): yellow gum; $[\alpha]_{\mathrm{D}}^{23.5}-11.0$ (c 0.23 , $\mathrm{MeOH}) ; \mathrm{UV}(\mathrm{MeOH}) \lambda_{\max }(\log \varepsilon) 289$ (3.27), 214 (4.01), 191 (3.76) nm; IR (KBr) $v_{\max } 3424,3081,2924,2853,1639,1619$, 1496, 1423, 1230, 915, $826 \mathrm{~cm}^{-1}$; ${ }^{1} \mathrm{H}$ and ${ }^{13} \mathrm{C}$ NMR data, see Table 1; negative ESIMS $m / z 333[\mathrm{M}-\mathrm{H}]^{-}$and isotopic peak $m / z 335[\mathrm{M}-\mathrm{H}]^{-}$; negative HRESIMS $m / z 333.0897[\mathrm{M}-\mathrm{H}]^{-}$ (calcd for $\mathrm{C}_{18} \mathrm{H}_{18} \mathrm{O}_{4} \mathrm{Cl}, 333.0893$ ) and isotopic peak $\mathrm{m} / \mathrm{z}$ $335.0908[\mathrm{M}-\mathrm{H}]^{-}\left(\right.$calcd for $\left.\mathrm{C}_{18} \mathrm{H}_{18} \mathrm{O}_{4} \mathrm{Cl}, 335.0864\right)$.

Manneoinsigin B (2): yellow gum; $[\alpha]^{23.5}-14.6(c$ 0.11, $\mathrm{MeOH}) ; \mathrm{UV}(\mathrm{MeOH}) \lambda_{\max }(\log \varepsilon) 289$ (3.49), 212 (4.20), 196 (3.84) nm; IR (KBr) $v_{\max } 3426,3080,2927,2856,1638,1624$, 1496, 1230, 917, $830 \mathrm{~cm}^{-1}$; ${ }^{1} \mathrm{H}$ and ${ }^{13} \mathrm{C}$ NMR data, see Table 1; negative ESIMS $m / z 333[\mathrm{M}-\mathrm{H}]^{-}$and isotopic peak $m / z 335$ $[\mathrm{M}-\mathrm{H}]^{-}$; HREIMS $m / z 334.0964[\mathrm{M}]^{+}$(calcd for $\mathrm{C}_{18} \mathrm{H}_{19} \mathrm{O}_{4} \mathrm{Cl}$, 334.0972) and isotopic peak $\mathrm{m} / \mathrm{z} 336.0961[\mathrm{M}]^{+}$(calcd for $\left.\mathrm{C}_{18} \mathrm{H}_{19} \mathrm{O}_{4} \mathrm{Cl}, 336.0942\right)$.
Cytotoxicity Assay. The following human tumor cell lines were used: HL-60, MMC-7721, A549, MCF-7, and SW480. All cells were cultured in RPMI-1640 or DMEM medium (Hyclone, Logan, UT), supplemented with $10 \%$ fetal bovine serum (Hyclone) at $37^{\circ} \mathrm{C}$ in a humidified atmosphere with $5 \%$ $\mathrm{CO}_{2}$. Cell viability was assessed by conducting colorimetric measurements of the amount of insoluble formazan formed in living cells based on the reduction of 3-(4,5-dimethylthiazol-2yl)-2,5-diphenyltetrazolium bromide (MTT) (Sigma, St. Louis, MO). ${ }^{19}$ Briefly, $100 \mu \mathrm{L}$ of adherent cells was seeded into each well of a 96-well cell culture plate and allowed to adhere for $12 \mathrm{~h}$ before drug addition, while suspended cells were seeded just before drug addition, both with an initial density of $1 \times 10^{5}$ cells $/ \mathrm{mL}$ in $100 \mu \mathrm{L}$ of medium. Each cell line was exposed to the test compound at various concentrations in triplicate for 48 $\mathrm{h}$, with cisplatin and paclitaxel (Sigma) as positive controls. After the incubation, MTT $(100 \mu \mathrm{g})$ was added to each well, and the incubation continued for $4 \mathrm{~h}$ at $37{ }^{\circ} \mathrm{C}$. The cells were lysed with $100 \mu \mathrm{L}$ of $20 \%$ SDS- $50 \%$ DMF after removal of $100 \mu \mathrm{L}$ of medium. The optical density of the lysate was measured at $595 \mathrm{~nm}$ in a 96-well microtiter plate reader (Bio$\mathrm{Rad} 680$ ). The $\mathrm{IC}_{50}$ value of each compound was calculated by Reed and Muench's method. ${ }^{20}$

\section{Electronic Supplementary Material}

Supplementary material is available in the online version of this article at http://dx.doi.org/ 10.1007/s13659-012-0063-7 and is accessible for authorized users.

\section{Acknowledgments}

This project was supported financially by the NSFC (No. 20802082 and 30830115 ), the projects from the Chinese Academy of Sciences (KSCX2-EW-Q-10 and KSCX1-YW-R24), the Major State Basic Research Development Program of China (No. 2009CB522300 and 2009CB940900), and the Natural Science Foundation of Yunnan Province (2012FB178 and 20080A007) and the project of recruited top talent of sciences and technology of Yunnan Province (2009C1120).

Open Access This article is distributed under the terms of the Creative Commons Attribution License which permits any use, distribution, and reproduction in any medium, provided the original author(s) and source are credited.

\section{References}

[1] Youn, U. J.; Chen, Q. C.; Jin, W. Y.; Lee, I. S.; Kim, H. J.; Lee, J. P.; Chang, M. J.; Min, B. S.; Bae, K. H. J. Nat. Prod. 2007, 70, $1687-1689$

[2] Watanabe, K.; Watanabe, H. Y.; Goto, Y.; Yamamoto, N.; Yoshizaki, M. Jpn. J. Pharmacol. 1975, 25, 605-607.

[3] Watanabe, K.; Watanabe, H.; Goto, Y.; Yamaguchi, M.; Yamamoto, N.; Hagino, K. Planta Med. 1983, 49, 103-108.

[4] Watanabe , K. Gendai Toyo Igaku 1986, 7, 54-59.

[5] Teng, C. M.; Yu, S. M.; Chen, C. C.; Huang, Y. L.; Huang, T. F. Life Sci. 1990, 47, 1153-1161.

[6] Bae, E. A.; Han, M. J.; Kim, D. H. Planta Med. 1999, 65, 442443.

[7] Namba, T.; Tsunezuka, M.; Hattori, M. Planta Med. 1982, 44, $100-106$

[8] Sohn, E. J.; Kim, C. S.; Kim, Y. S.; Jung, D. H.; Jang, D. S.; Lee, 
Y. M.; Kim, J. S. Life Sci. 2007, 80, 468-475.

[9] Fukuyama, Y.; Otoshi, Y.; Miyoshi, K.; Nakamura, K.; Kodama, M.; Nagasawa, M.; Hasegawa, T.; Okazaki, H.; Sugawara, M. Tetrahedron 1992, 48, 377-392.

[10] College, J. N. M. Ed. Chinese Drug Dictionary. Shanghai Science and Technology Publishing Co. 1977, 1628-1630.

[11] Vardamides, J. C.; Azebaze, A. G. B.; Nkengfack, A. E.; Van Heerden, F. R.; Fomum, Z. T.; Ngando, T. M.; Conrad, J.; Vogler, B.; Kraus, W. Phytochemistry 2003, 62, 647-650.

[12] Sugahara, T.; Yamauchi, S.; Kondo, A.; Ohno, F.; Tominaga, S.; Nakashima, Y.; Kishida, T.; Akiyama, K.; Maruyama, M. Biosci. Biotechnol. Biochem. 2007, 71, 2962-2968.

[13] Masuda, T.; Akiyama, J.; Fujimoto, A.; Yamauchi, S.; Maekawa, T.; Sone, Y. Food Chem. 2010, 123, 442-450.
[14] Luo, X.; Wu, S.; Ma, Y.; Wu, D. Acta. Bot. Yunnanica 2001, 23 , 368-372.

[15] Deng, X. M.; Cheng, Y. X.; Zhou, J.; Tan, N. H.; Ding, Z. T. Acta Bot. Yunnanica 2001, 23, 121-125.

[16] Shen, C. C.; Ni, C. L.; Shen, Y. C.; Huang, Y. L.; Kuo, C. H.; Wu, T. S.; Chen, C. C. J. Nat. Prod. 2009, 72, 168-171.

[17] Otsuka, H.; Takeuchi, M.; Inoshiri, S.; Sato, T.; Yamasaki, K. Phytochemistry 1989, 28, 883-886.

[18] Takeshita, M.; Yaguchi, R.; Akutsu, N. Tetrahedron: Asymmetry 1992, 3, 1369-1372.

[19] Ping, Z. R.; Hongjie, Z.; Zhongwen, L.; Yulin, Z.; Handong, S. Phytochemistry 1992, 31, 4237-4240.

[20] Reed, L. J.; Muench, H., In Am. J. Hyg. 1938, 27, 493-497. 